\title{
Teologie in 'n tyd van Sekularisme
}

\section{INI.EIDING;}

Oorspronklik was dit die bedoeling om slegs die werke van Kuitert (Realiteit ran het geloof), A. C. Porteous (Prophetic voices in comtem. porary theology) en Heyns (Die erangelie in die krisis) te bespreek. Maar die vraagstuk het almeer geboei. Al gaande het die artikel in omvang gegroei en het dit duidelik geword dat ons hier met die teologiese vraagstuk van ons tyd te doen het.

In werklikheid gaan dit om 'n dogmaties-filosofiese problematiek. maar die Skrif en die eksegese is daar ten nouste mee gemoeid. Dikwels word beklemtoon dat dit gaan om die hermeneutiek en dit is ook so. hocwel die skrywers oor die algemeen nie met die hermeneutiek as teorie van eksegese besig is nie en dit by die eksistensialiste gaan om die akte van die verstam, eerder as oor die verstan van die Skrif. So kan dit begryp word dat 'n eksegeet moontlik ook 'n woordjie kan meespreek.

Dic eksegeet moes vir dic uilcensetting van die standpunte van die teolö̈ van die sekularisme (of eksistensie-teoloë as u wil) noodwendig gebruikmaak van die uiteensettinge van ander. om die eenvoudige rede dat dit teenswoordig in onbegonne taak is om op alle terreine met die bronne vertroud te wees. Ons wil aanvaar dat die werke wat geraadpleeg is aan hulle onderwerp reg laat wedervaar het.

\section{SEKULARISASIE EN SEKLII.ARISME}

Tussen hierdie twee begrippe moet goed onderskei word. B. Rietveld $^{1}$ sê tereg dat onderskeid gemaak moet word tussen die vrymaking van die valse religieusiteit enersyds en onttrekking aan die binding van die Heilige Skrif andersyds. Eersgenoemde kan sekularisasie genoem word en hoef nie altyd in in verkeerde sin verstaan te word nie. Volgens Newbigin is dit in historiese proses waaraan hy en sy lesers deel het. Negatief beteken dic woord die onttrekking van lewenssfere en -aktiwiteit aan die kontrole van georganiseerde religieuse ligganc. en die onttrekking van gedagtesfere uit die kontrole van wat in die geloof as geopenbaarde waarhede aanvaar is.

Positief kan dit gesien word as die groeiende beklemtoning van die kompetensie van die menslike wetenskap en tegniek om menslike probleme van enige aard te kan hanteer. ${ }^{2}$

Gedeeltelik kan ons hiermee saamstem. maar ons sou die ont. trekking van gedagtesfere uit die kontrole van wat in die geloof as geopenbaarde waarhede anvaar is.. liewer as sekularisme beskou (vgl. onder). Die positiewe sou ons liewer wou beskryf as die regte waardering van die menslike wetenskap. sonder dat ons kan danvaar dat dit kompetent is om menslike probleme van enige aard te hanteer. 
Volgens Newbigin verwys die woord ..sekularisme" na 'n sisteem van geloof, of ' $n$ houding. wat in beginsel die bestaan of betekenis ontken van ander realiteite as dié wat gemeet kan word deur die metodes van die natuurwetenskap. Op jie Jerusalemse vergadering van die International Missionary Conncil is dit gedefinieer as ,.a way of life and an interpretation of life that include only the natural order of things and that do not find God, or a realm of spiritual reality, necessary for life or thought".

In hierdie artikel handel ons oor sekularisme.

\section{I. DIE PROBLEEM}

Bremmer vat die problematiek saan in die volgende woorde: „Hoe is het mogelijk als moderne mens. als Christen van de twintigste eeuw met zijn technologische ontwikkeling. zijn voortschrijdende urbanisatie, zijn ruimtevaart en secularisatie. in God te blijven geloven en het Evangelie als bron van Godskennis te blijven aanvaarden?'”s

Dieselfde skrywer beklemtoon die feit dat die problematiek tans heeltemal anders is as in die tyd tussen die twee wêreldoorloẹ. Toe het Barth die veld beheers. Hy het hom besig gehou met die materiële inhoud van die Dogmatiek (die leer oor die Skrif. (Gol ens.). Nou word gevra: hoe lees die moderne mens die Bybel? Watter beeld vorm ons ons aangaande God? Sề die Woord van God vir ons nog iets?

Ons kan met Bremmer saamstem, in sover dit iemand soos J. A. T. Robinson betref, dat nie "n growwe ateisme bedoel word nie. Maar dit neem nie weg dat daar wel teoloë is wat die uiterste konsekwensies trek nie.

Die jongste werk van Altizer dra die ondubbelsinnige titel: The gospel of Christian atheïsm. Dit word duidelik uitgespreek: "There was once a God to whom adoration. praise and trust were appropriate, but .... now there is no such God"."

Gilkey sien ten minste vyf leidende beginsels wat die nuwe teologie karakteriseer: 1. Die verwerping van God; 2 . die aanvaarding van die sekulère wêreld; 3 . die verwerping van outoritatiewe openbaring of tradisie; 4. 'n nadruk op die sentraliteit van die historiese Jesus; 5. die onderskrywing van 'n radikale empirisme of fenomenalisme."

Kuitert spreek van 'n ,anti-metafisiese tendens”. ${ }^{\circ}$ Met die woord "metafisies" bedoel hy dat daar nie alleen 'n voorhande voorgrondswêreld is wat ons sien en ken nie, maar ook 'n onsienlike agtergronds. wêreld - die wêreld van God in sy wese, woorde en handele, en dat ons oor hierdie wêreld eweseer algemeen-geldige uitsprake kan doen as oor die eerste. Die anti-metafisiese tendens vra: Kan daar oor God en sy openbaring uitsprake gedoen word wat algemeen-geldig is? ls teologiese uitsprake ewe algemeen-geldig as ander wetenskaplike uitsprake. d.w.s.: geld hulle ook vir ander gelowiges, ja vir die ganse mensheid?

Met die strekking van die woorde van Kuitert kan ons saamstem. hoewel die terme ,.metafisies", net soos ,intra- en ekstra-kosmies" 
wat ons dikwels hoor, liewer vermy moet word. Dit pas in die kraam van hulle wat ons gerieflikheidshalwe maar .,eksistensieteoloë" noem. Húlle het juis beswaar dat van God gedink word as in wese wat ..up there" is, ..an old man in the sky" (hoe lasterlik dit ookal klink). Ons kan gerus maar bly by Bybelse terme. God is wel hoog verhewe, maar tog ook alomteenwoordig (vgl. Psalm 139) en by die verbrokene en verslaene van gees.

Die nuwe teologie vra: As u spreek van die realiteit. die werk. likheid van die geloof. bedoel u die werklikheid warop die geloof hom rig en waaraan dit die woord wil gee? Of bedoel u die werklikheid van die geloofsakte self"? As ons sê: ..God is". of ..Jesus is opgewek", verlel die uitsprake iets oor God. respektiewelik wat gebeur het met Jesus van Nasaret, of sê dit iets oor onsself?

Die groot omslag wat plaasgevind het, en reeds by Schleiermacher aan die begin van die negentiende eeu 'n aanvang geneem het. beteken dat as ons spreek van die realitas fidei, die genitivus verstaan word as 'n genitivus subjectivus en nie-objectivus nie.'

Hierdie dinge het nie net teologies-wetenskaplike implikasies nie. maar gryp ook diep in die geloof van die gemeente in. Die vraag is vir prediker en hoorder: Is God meer as ver-beeld-ing van ons diepste verlangens?

Daarmee hang 'n ander vraag saam: die verkondiging ontleen sy boodskap aan die Bybel. Maar die Bybel stam uit 'n heeltemal ander tyd as dié van ons en - wat beteken die Bybelse woorde vir ons in hierdie tyd?

Van die kant van die teoloog en die gemeentelid wat aan die Bybel trou bly word weer aan die adres van die genoemde teoloë die vraag gerig: Is die weg van die rasionele en empiriese denke die enigste weg tot kennis van die werklikheid? Het die volle werklikheid nie meer as cen benadering nodig nie?

Watter teologie moet ons dan stel teenoor die gesekulariseerde? Voordat ons hierop in antwoord probeer gee. skets ons eers die historiese verloop sedert die Reformasie van die sestiende eeu.

\section{DIE HISTORIESE AANI.OOP}

Dit val dadelik op dat die formuleringe van die Lutherse en Gereformeerde Skolastick van die 17 de en 18 de eeue aangedien word as algemeen-geldige waarhede met in objektiewe gehalte juis dit wat die teenswoordige rigtinge as problematies beskou. Geloof beteken die vir-waar-hou van die verskillende veritates supernaturales et naturales van die theologia revelata, tot 'n so logies-moontlike geheel verwerk."

in Duidelike voorbeckl word gevind in die feit dat die ortodoksie van die 17de en 18de eeu die sg. .. (joxlsbewyse" as werklike beuyse opgevat het. Dit blyk dat in die bekende werk van vier Gereformeerde teologiese professore van Leiden in die sewentiende eeu. bewyse uit die werke van Aristoteles van dieselfole bewyskrag is as dié wat aan die Shrif ontleen is. 
Hier is nou 'n voorbeeld van 'n teologie wat as metafisika opgebou is. As die sg. antimetafisiese tendens hierteen gerig is, dan volkome tereg. Ons stem met Kuitert saam as hy verklaar: „Deze nauwe verbinding tussen Christelijke geloofsleer en metafysisch leersystcem, blijkt in de geschiedenis - zooals elke al te directe binding van de theologie aan een bepaalde filosofie - een riskante zaak. Wordt de metafysica als filosofisch systeen ondergraven. dan valt daarmee het steigerwerk dat de theologische en dogmatische constructies overeind hield"."

Van drie kante het daar opposisie gekom teen die Protestantse Skolastiek, naamlik van die Piëtisme, die historiese denke en die natuurwetenskappe. Ons gee hier slegs aandag aan die Piëtisme, omdat dit baie naby verwant is aan die gesekulariseerde teologie van ons tyd. Die natuurwetenskappe kom ter sprake by die probleem van die ,wêreld. beeld".

Die Piëtisme beklemtoon die feit dat die veritas $\mathrm{n}$ beleefde, ervare waarheid moet wees, sodat die belangstelling vir in groot deel in die rigting van die subjektiewe gaan. Schleiermacher kan ook in 'n sin hierby gereken word. Sy kontensie is dat die waarheid histories is (net soos die mens) en dus versk!niwend, altyd in ontwikkeling en gestempel deur die kultuur en beskawing van in bepaalde periode. Dit gekl ook vir die Bybelse waarheid. Die godsdiens bestaan nie in die handhawing van ,natuurlike” of ",bonatuurlike” waarhede nie. maar het sy eie ..Provinz in Gemuith". Die teologies-dogmatiese uitspraak is ' $n$ uitkristallisering van die godsdienstige oerervaring van die mens in woorde. in taal. As die eis gestel word dat aan hierdie uitsprake werklikheid moet beantwoord, verklaar Schleiermacher dat werklikheid in hierdie geval nie die sg. objektiewe werklikheid van die ortodoksie is nie, maar die subjektiewe. Dit is duidelik dat die ontwikkeling van vandag veral by Schleiermacher aanknoop, maar dit kan ook "n kras vorm van Piëtisme genoem word."

Bremmer ${ }^{11}$ meen dat deur J. H. Scholten in die negentiende ceu soortgelyke vrae gestel is. Hy wou ook weet hoe die ..moderne" mens aansluiting by die evangelie kan vind, hoe kerk en wetenskap met mekaar versoen kon word. Sy oplossing lê in die ooreenstemming van die Skrif met die menslike rede. Maar terselfdertyd wil hy onderskei tussen die Skrif as die historiese en die Woord van God as die religieuse waarheid. Hy wou (in moderne terminologie) die Skrif eksistenieel verstaan.

Van belang is in hierdie verband die feit dat Scholten onder die invloed van Hegel gestaan het en Bremmer is van gevoele dat dic papiere van Hegel weer besig is om te styg. wat beteken dat die teologie nie meer in so "n sterk mate deur die eksistensiefilosofie beheers word nie. ${ }^{12}$

Ook in ander opsigte kan spore van die negentiende eeu bemerk word. Volgens Van Niftrik herleef mutatis mutandis Ritschl weer in Paul van Buren. sowel as Schleiermacher. Vir hom gaan naamlik die religie op in sedelikheid en soos vir Schleiermacher (iod nie ...osgewikkel" kan word uit die vroom gevoel nie, so kan volgens Van Buren 
God nie losgewikkel word uit die liefdeshandeling teenoor die naaste nie. ${ }^{13}$

Die kreet wat as skokterapie bedoel is (naamlik: God is dood) vind 'n mens reeds by Hegel wat in $18(12$ reeds van die "Tot Gottes" gespreek het en dit genoem het die ..Grundgefühl der Religion der Neuzeit". Hegel het die heilsfeite en hulle boodskap verfilosofeer en dieselfde het in die moderne tyd met Bonhoeffer gebeur. ${ }^{14}$

Barth het al in 1964 verklaar dat die op ontmitologisering en hermeneutiek gebaseerde teologie in sterk terugval na die negentiende eeu vertoon. maar eintlik ver ten agter bly in vergelyking daarmee. Daar word byvoorbeeld maar weinig van die diepte van die romantiek en die hoogte van die spekulasie van Schleiermacher en Biedermann gevind.

F. H. Klooster wil nog verder teruggaan: ..A survey of the historical background of the death-of-God-theology leads along a sad line of apostasy and attempted human economy back from nineteenth century I.iberalism through the eighteenth century Enlightenment or Aufklärung on to the humanistic Renaissance (1.350-1550)." Die Renaissance het reeds die kultuur gesekulariseer. Die belangstelling was vir die hier en nou. Ook in die Aufklärung is ' $n$ poging aangewend om God te skei van sekere lewensterreine.1"

Altizer wil selfs beweer dat die radikale teologie van vandag geinisieer is deur Barth en die neo-ortodoksie. Die neo-ortodoksie was op sy beurt 'n reaksie teenoor die Liberalisme van die 19de eeu. So is die .God-is-dood-teologie"weer "n reaksie teen die neo-ortodoksie en 'n terugkeer na die I iberalisme. ${ }^{16}$

Volgens (iilkey het hierdie beweging van Barth die radikale skeiding tussen die Goddelike en die sekulêre geërf. Hulle het slegs die negatiewe elemente oorgehou van die neo-ortodokse dialektiek en openlik die positiewe aspekte verwerp. Immers. Barth het tog nog 'n positiewe nadruk gelê op God en die openbaring deur die Woord. Hierdie element word in die nuwe radikale teologie gemis. Bonhoeffer word aangewys as dic brug van neo-ortodoksie na neo-liberalisme. Verder word ook invloede van kierkegaard en Heidegger bemerk.

So het ons dan - volgens Bremmer ${ }^{1}$ - uitgekom by 'n heeltemal ander klimaat as dié van die eksistensiefilosốie. Terwyl hierdie filosofie groot nadruk lê op die ..moment van beslissing" is ons by Robinson (en Tillich) in 'n heeltemal ander sfeer. Die mens wat dit by al die dodelike beslissinge van die cksistensiewysegere nie meer kon uithou nic, soek nou rus in iets wat die mens dra en hom stu tot 'n sinvolle. relelike bestaan. Dit gaan om "the ultimate concern", on die erken. ning van die ..transsendente. onvoorwaardelike element", die ..Ground of Being".

\section{VERSKIIIIFNIDE IFIGIIRE" \\ R. Bultmamm:}

Oor Bultmann spreek ons hier nie uitvoerig nie. aangesien $H . N$, Ridderbos sy standpunt onlangs in in lesing behandel het. 
Bultmann wil dat die evangelie op die ware menssyn van die mens betrek moet word - die Skrif moet dus eksistensialisties verklaar word. Maar aangesien die boodskap van die Skrif in talle mites gegiet is. sal hulle eers ..verwyder" of liewer .,hegryp" moet word contnitologisering).

Daar moet verder onderskei word tussen lorm en kern. Die kern van die evangelie, naamlik die heilsgebeure in Christus is nie aan ' $n$ bepaalde tyd. omstandighede of vorme gebind nie. In ons tyd sal die kern verstaan moet word vanuit. en aansluit by, die lewensen wêreldbeskouing van ons dag, en dit kom in eksistensiefilosofie tot uitdrukking, veral dié van Heidegger.

Die mite bedoel dan ook oorspronklik die selfontdekking van die mens en die teologie is in sekere sin antropologie, uitsprake oor en in die menslike eksistensie.

F. Buri:

Buri is woordvoerder van die linkergroep van Switserse teoloë wat hulle krag soek in 'n nuwe godsdienswysgerige deurdenking van die tradisie. Hy steun veral op die eksistensiefilosofie van Jaspers en wil verder gaan as Bultmann -.. die Skrif moet nic net ontmitologiseer word nie, maar ook omtkerugmatiseer. Vir hom is daar prisipieel geen verskil tussen teologie en filosofie nie.

\section{Bonhoeffer:}

Hy gaan uit van die gedagte van die ..mondige mens" van ons tyd wat die godsdiens nie meer nodig het nie, d.w.s. die godsdiens soos hy dit in sy omgewing vind. Hierdie godsdiens het meganisties geword. God is 'n deus ex machina wat van buite kom om sy kinders te help as hulle in moeilikheid is en daarna weer terugkeer. Die godsdiens is kompartementulisties, aangesien dit net as 'n deel van die lewe gesien word, met die gevolg dat wetenskaplike en ander ontdekkinge die godsdiens al meer en meer na "n onbeduidende posisie terugdring. Dit is metafisies want God is die bomatumrlike element. Ten slotte is dit individnalisties. Die godsdienstige mens is primêr met homself besig en stel geen belang in sy naaste nie. Die wêreld word aan homself oorgelaat. ( $\mathrm{m}$ hierdie rede staan die mondige mens nader aan (iod as die onmondige. wie se godsdiens so pas getipeer is.

Bonhoeffer vra nou: Hoe moet die boolskap van die Bybel aan die mondige mens gebring word? Sy antwoord is: Ons moet solidêr word met ons godsdienslose wêreld om so te laat sien dat (jod tóg daar is, dat Hy heers en dat ons wag op die koms van sy koninkryk. Ons moet so lewe dat deur ons swye die stem van (jol gehoor word.

Bonhoeffer pleit vir 'n Christosentriese opvatting van die werklikheid. In Jesus Christus het die werklikheid van (jod die werklikheid van hierdie wêreld binnegegaan. (jod word soseer met die mens Jesus Christus vereenselwig dat Hy nouliks meer is as Jesus Christus.

Christus moet in die sentrum van die wêreld ontdek word, nie in die periferie nie. Daarom moet die mens ook midde in die wereld wees vir die wêreld. Waar die lewe met al sy probleme en verplig- 
tinge nie ernstig geneem word nie, en dit alleen maar gaan on dogma's. titels en instellinge -- soos deur die offisiële godsdiens verkondig daar is die genade wat verkondig word goedkoop.

Bonhoeffer pleit vir duur genade; duur omdat dit oproep tot egte dissipelskap. wat selfs 'n mens se lewe kan kos, soos dit die geval met Christus was. Sy teologie is by uitstek 'n teologie van die kruis. Hy lé nadruk op die ..onmag" van Christus aan die kruis. sy solidariteit met armes en verdruktes. So moet elke mens en die kerk opgeroep word tot radikale menswees.

Bonhoeffer is genoem dic .,Johannes die Doper" van die ,nuwe reformasie". terwyl Niebuhr hom beskryf het as iemand wat behoort tot die moderne ..Handelinge van die Apostels". Hy het dan ook waarlik die .,kosie van dissipelskap" betaal -- soos die titel van sy cerste boek lui. Kuitert spreek van ..de grootheid van deze man". Soos bekend is, het die Nazibewind hon die galgdood laat sterf. By alle waardering vir hierdie man moet egter ook sý teologie aan die Skrif getoets word.

\section{P. Tillich:}

Volgens sy eie verklaring het hy ..op die grens" geleef: die grens tussen geloof en twyfel: tussen filosofie en teologie; tussen die ou- en die nuwe wêreld; tussen die Christendom en die ander godsdienste; tussen Protestantisme en Katolisisme: tussen I.iberalisme en Neoortodoksie.

Die verskil tussen hom en ander teoloë van hierdie rigting is dat hy -. volgens Porteous -.. brûe geslaan het waar die ander Berlynse nure gebou het. Net soos Bultmann wil hy die Christelike geloof 'n lewende opsie maak vir die moderne mens.

Tillich is oortuig dat sowel die Fundamentalisme as die Barthiaanse gerukmatiese teologie misluk het omdat hulle in hul teologie die konkrete situasic waarin die teologic ontvang moet word. ignoreer. Fundamentalisme doen dit deur te spreek van in situasie in die verlede: Barthianisme deur enige werklike kontak tussen die Christelike geloof en die kulturele aktiwiteit van die mens en sy gedagtes te ontken. soxlat die evangelic as "t ware ..soos "n klip" na hulle gegooi word. So 'n teologie gee nie 'n antwoord op die vrae van die mense nie. wat die groot rede is waarom hulle wegdrywe van die kerk.

Tillich verskil van Bultmann daarin dat mites vir hom geloofssimbole is wat aan mekaar verbind is in verhale in verband met .goddelik-menslike ontmoetinge". Hy wil dus nie ontmitologiseer nie. maar deliteraliseer (ontletterlik). Die feit dat simbole letterlik verstaan is, was volgens hom die struikelblok vir baie wat van die Christendom geëmansipeer is.

Hy wil nie beweer dat (iod nie werklik bestaan nie. ook nie dat Hy onderskei moet word van ons wêreld nie, "but that $\mathrm{He}$ is precisely that reality with which we are most intimately, profoundly. and indeed. disturbingly confronted". (ioxl is nie "n wese ..up in the blue". wat Russiese astronaute moontlik eendag kan lokaliseer nie. Hy is die 
grond van ons bestaan, nie in Persoon in die sin waarin ons persone is nie, maar die Grond van al wat persoonlik is, dus - suprapersoonlik.

Porteous meen dat daar 'n profetiese gees is wat al die werke van Tillich deurstraal. Hy het sy massiewe teologiese ..span" gegooi oor die verskillende grenslyne wat die antwoorde van die Christelike openbaring afskei van die moderne mens.

\section{R. Niehuhr:}

Wat Barth vir Europa beteken het, was Niebuhr vir Amerika. Sy teologie het vir die meeste Amerikaanse denkers 'n meer kongeniale brug vanaf die Liberalisme na die neo-ortodoksie verskaf as Barth in sy eerste periode. Hy toon die relevansie van die Bybel vir die komplekse probleme van die moderne gesekulariseerde wêreld aan. Porteous noem sy teologie 'n .,down-to-earth Christian realism'.

Nadat hy 'n keer deur 'n kollega met 'n groot Packard tuisgebring is, het hy in sy dagboek aangeteken: "Ministers who can preach the gospel of Jesus without making anyone uncomfortable deserve an automobile for the difficult feat. And they need one to compensate them for that lack of spiritual vitality which makes the performance of the feat possible." Hy merk ook op: "I'm not surprised that most budding prophets are tamed in time to become harmless parish priests."

Net soos Tillich is hy gekant teen die literalisme in die Bybelverklaring. Hy spreek bv. van ..die mile van die sondeval" wat nie ietterlik verstaan mag word nie. Die verhaal van Genesis 3 is nie dié van die eerste historiese mens nie. maar die verhaal van Everyman. die verhaal van elkeen van ons wat beswyk vir die versoeking van self God te probeer wees.

\section{J. A. T. Robinson:}

Dit is opmerklik dat Robinson nie aanknoop by Barth en Brunner nie - wat vir hom blykbaar te ortodoks en te kerklik was -.. maar by dié teoloë wat beweer dat hulle ..aan den lijve" ondervind het dat die kerk met sy boodskap misluk het. byvoorbeeld in die loopgrawe van die eerste wêreldoorlog (Bultmann en Tillich) en dic konsentrasiekampe gedurende die tweèle wêreldoorlog (Bonhoeffer).

Die moderne mens - aldus Robinson - verstaan die geloofstaal nie. omdat dit mitologies en supranaturalisties is (à la Tillich) en religieus (Bonhoeffer).

"n Groot struikelblok vir Robinson is die sg. .,wêreldbeeld" van die Bybel. waarin dit sou voorgestel word dat die heelal uit drie verdiepinge bestaan: hemel, aarde en waters onder die aarde. As die moderne sterrekundige nou aantoon dat die drie verdiepings nie bestaan nie, waar is God en waar is die hemel dan?

Hy wil sy antwoord beskou as 'n Copernicaanse omwenteling. God is nie daurbuite nie maar hier bimme. Hy is die Cirond en die Diepte van die bestaan. 


\section{P. lam Bure'l:}

Waar Bultmann. Robinson e.a. meer aandag gee aan die buitekerklikes roep Van Buren die Christen en die kerk op om ..eerlik te wees temoor hulself". Sy wagwoorde is: eerlikheid. sindelikheid. klaarheid van denke. Die hele week leef ons op sekulêre wyse in "n moderne wêreldbeekl en meteens moet ons Sondag probeer om onsself te verplaas in 'n supranaturalistiese wêreld met God, 'n hemel. engele en demone. Dit beskou Van Buren as 'n soort schizofrenie. Hy is hom. self bewus dat sy stelsel in reduksie van dic teologie beteken maar ..we have left nothing essential behind".

Kenmerkend is die volgende uitspraak: "The problem lies in the word ' $\mathrm{jod}$ ' itself. and in any other word supposedly referring to the 'transcendent' ... . Today we cannot even understand the Nietzschian cry that 'Gorl is dead'. for if it were so, how could we know? No, the problem is that the word "God" is dead".

Dit gaan dus nog verder as wat Heyns beweer wanneer hy sê dat vir Van Buren nog slegs die woorde God en Christus bestaan.

\section{T'illhard de Chardin:}

Die groot doel van hierdie Roonse geoloog en paleontoloog is om dic Christendom en dic noderne wêreldbeeld te probeer versoen. IIy beskou elke opvatling waarin godsdiens en wetenskap van mekaar geskei word as skadelik in so "n mate dat die huidige krisis in die Westerse beskawing in geen geringe mate toegeskryf moet word aan die skeiding lussen die teologie en die ander wetenskappe. Die eenheid word volgens hom gevind in die Pauliniese leer van die kosmiese betekenis van Christus. Dit kan 'n teëwig wees teenoor die toenemende nihilisme en sinloosheid.

As omvattende verklaring danvaar hy die evolusiebegrip. Die heelal warin ons lewe is geen statiese grootheid nie. maar het 'n lang ontwikkeling deurgemaak. Aan die einde - of liewer die voorlopige cinde .... staan die mens. In en deur hom gaan die wêreld sy verdere voltooiing tegemoet.

Al die konvergerende lyne loop uiteindelik uit op in bepaalde punt, in 'n ho-persoonlike eenheid wat nie iets is nie maar lemand. Of dil God is weet ons nie. Hy praat van Omega. Maar in elk geval is God vir hom in dic wêreld as die betekenis en diepte daarvan. Hy deurstraul alles. Die kruis is die simbool op die weg van volmaakte deurstraling. Oorgawe aan (hristus is nie vervreending van die wêreld nic. maar corgawe aan die wêreld en in heel besondere sin ook oorgawe aan (jocl.

Met reg kan Heyns sê dat selfs die moderne mens nie veel kan hê dan so $\mathrm{n}$ spekulatiewe sintese nie.

\section{I. Megenuar:}

Hier het ons met in man van eie bodem (Stelenbosch) te doen. wat verklaar dal hy in gesckulariseerde mens is omdat hy een wil wees. 
Daar moet wees 'n onthegting van goderyke en "n gevolglike solidariteit met mens en wêreld. So alleen kan die aarde geopenbaar word as ,milieu van God".

Die mens van ons tyd is in nuwe mens en het behoefte aan in nuwe konsep van die Christelike geloof. Daarom is die teoiogic onnagtig in sy konfrontasie met die moderne mens. Mens en wêreld is losgemaak van alle buitewêreldse bindinge. soos religie en metafisika. Daar is dus behoefte aan $\mathrm{n}$ vernuwing van die teologiese denke volgens in fenomenologies-ontiese metode.

In die Bybelse verhale gaan dit nie om 'n relaas van feite nie. maar om verhale met 'n bepaalde tendens. Die vertellinge moet eksis. tensiaal en eksistensieel verstaan word. Die historisiteit van Adan en Eva moet nie beklemtoon word nie. maar die betekenis daarvan moet vasgestel word vir die mens se liggaamlike situasie hier en nou. Baie van die verhale van die Bybel kan geinterpreteer word as mites of as sinvolle vertellinge ontrent die menslike bestaan. (jeloof moct uit die vlak van dogma's in die sfeer van situasies en ontmoetinge geplaas word.

Die esgatologie is nie die leer oor die laaste dinge aan die einde van die tyd nie, maar oor die beslissende dinge vir elke tyd. Die ewige lewe is hier en nou.

Binne 'n evolusie-model kan sinvol wetenskap beoefen word. Dic Bybelse skeppingsverhaal is 'n mite. 'n gedig wat nic oor dic oorsprong van dinge handel nie, maar vertel van die sin en gerigtheid van die kosmos.

In die dood gaan die mens onherroeplik te gronde en daar bly niks oor nie. Die biologiese dood is die einde van die lewe wat mens en dier gemeen het. Maar die dood as beeindiging word ook verdiep tot die beeld van 'n eksistensiële dood as die voortdurende beëindiging midde in die lewe. (Die het vatten kan, vatte het, S.d.T.)

Dit skyn of Degenaar iets van elkeen van die voorafgaande het.

\section{J. J. Altizer en W. Ilamilton:}

Hulle word beskou as van die belangrikste verteenwoordigers van die ..dood-van-God-teologie". F. H. Klooster meen dat Van Buren ook by hulle hoort, maar laar is aanduidinge dat hy enige assosiasie met hulle repudieer.

Altizer en Hamilton het 'n versameling van hulle artikels gepubliseer, maar ook afsonderlike boeke. Altizer onder meer een met die sprekende titel: The gospel of Christian atheism. Hierdie titel tipeer die radikalisme van genoenude teoloc.

\section{OPI.OSSINGE WAT AANGEBIE.D WORD}

Drie voorstelle word genaak on dic mensdon in hierdic hrisis te help:

1. Daar word amknoping gesock by dic evangelieboodskap wal val egter op 'n heeltemal nuwe wyse aktued geinterpreteer moet word. 
2. Daar word tithreiding van die evangelie bepleit. Die waarheid is orals te vinde. ook buite die Bybel. en al die brokstukke moet in in onvaltende cenheid saamgevat word.

3. Daar word openlik gepleit vir verwerping van die Bybel. Die mensclom sal die beste gedien wees deur nie van die Bybel gebruik te maak nie. ${ }^{19}$

As voorbeeld van die tweede groep noem Heyns Karl Jaspers en onder die derde groep val: Nietsche. Sartre en Merleau-Ponty, Kommuniste en ateïste.

In hierdie artikel beperk ons ons tot die verteenwoordigers van groep 1 tot wie gereken kan word die figure wat reeds bespreek is.

Al dic denkers in hicrdic grosp wil doelbewus in vernuwingsteologie uitbou vir dic .moderne. mondige mens". Vir hierdie mens moet die evangelie aanvaarbaar gemaak word. Hulle sien vir hulself dus in missionêre taak.

\section{1. 'n Angshouding:}

Dit sien die sckularisne as 'n noodlot wat oor die denke gekom het. Dic skeppingsrykdom van die wiêreld word deur die natuurwetenskaplike denke en die legnick hos langer hoe neer afgeknaag en van sy glans beroof. Al wat oorbly is die rasioneel beheerbare en dit word nic warheid genoem nie. maar werklikheid en die werklikheid is die matenaties-fisiese natuur.

\section{Aanvarding:}

Hier word dic sekularisme in sy massiwiteil aanvaar, soos by Bultmann en Bonhoeffer.

Beide houdinge sien in die sekularisme in onvermydelikheid: die cerste as in te vrese fatum wat uilloop op die kreet van Nietzsche: God is dood! Die tweede sien daarin in positief te waardere einde van 'n illusic.

\section{BEOORDEI.ING; VAN DIE SEKULARISME}

Tot 'n beoordeling word ons genoodsaak deur die naakte feit dat ons nie by die teolö van die nuwe rigting skouer-ophalend verby' mag gaan nie. Van Niftrix wys net reg daarop dat ons wat die teologie betref "n spannende tyd tegemoetgaan en dat ons vermoedelik "n heropbloci vain die vrysinnigheid kan 1 erwag soos in die 19de eeu.to

Maar ons moet nie bloot negativisties optree nie. Allereers is introspeksic nodig. Dit is heel genuklik on dic eksistensieteologie sy konneksies met lieidegger te verwyt. maar die ortodoks-reformatoriese tradisie kan net so maklik betrap word op sy konneksies met Aristoteles. -1

Bremmer vra: "Is het spreken van de orthodoxe Dogmatiek over (ioxl opgewassen tegen de vloed van kritick dic ons uit deze nieuwe theologie tegemoetkomt? . . . Is de wijze watrop de (iereformeerde dogmatiek (sinds hatar vernieuwing door Kuyper en Bavinck) de (jods. 
leer uitwerkte, voldoende bewerktuigd om hier de begaanbare weg to bewandelen"?":-"

$\mathrm{Hy}$ is van oordeel dat ons die Dogmatiek van hierdie manne simpateties-krities moet benader. Wat Bavinck betref is dit opvallend hoe sy Godsleer beheers word deur metafisies-wysgerige gedagtes. Veral die uit die thomistiese teologie stammende onderskeiding tussen God as die onbewoë Synde teenoor die skepping as die wordende. speel daarin ' $n$ rol. maar dwarsdeur die filosofiese onderskeidinge word ook allerlei Skriftuurlike motiewe gevind. Maar as Bavinck die Raad van God bespreek as die wêreldidee, die causa exemplaris van die skepping. word die vraag dringend of hier nie 'n filosofiese oorwoekering is van die konkrete spreke van die Skrif oor Gorl nie."3

Wat Kuyper betref het Volten aangetoon dat hy sekere begrippe soos stof en vorm, potensie en akte. regstreeks aan die Thomistiese filosofie ontleen het. Verskillende skrywers het ook by hom invloede van Plato ontdek. In die skeppingsleer word 'n gechristianiseerde Aristoteles gesien.

Berkouwer het daarop gewys dat dit in uiters gevaarlike Skrifkritiek is as ons die Skrif onderwerp aan ons gedagtespinsels.

Ons tradisionele teologie is diepgaande beinvloed deur die Ciriekse synsleer, waarin veral getrag is on te omskrywe wát die dinge is. Cod word 'n ewige ..Wese", met tal van eienskappe. mededeelbare en onmededeelbare."

Nog iets oor ons sielehouding in die beoordeling. Van Niftrik merk op dat die dogmatikus dikwels die bewoendheid. die imnerlike ontferming van Jesus met die skare mis. Wat Christelike geloof is, moet gesê word, maar ook beleef word, deur mense wat self gegryp is.

Ons moet ook bereid wees om te erken dat die eksistensieteologie sekere vrugte afgewerp het. ,.Elke ketter het sy letter”.

\section{Die sentrale plek van die Hermeneutiek:}

'n Belangrike vrug is dat die eksistensieteologie ons die sentrale plek van die Hermeneutiek aangewys het. As ons teologie werklik Skrifteologie wil wees moet dit hiervan met dankbaarheid kennis neem. Dit is ' $n$ hoofsaak: Hoe lees ons die Bybel só dat ons dit verstaan? (vgl. Hand. $8: 35$ ).

Die eksistensieteologie sien die taak vir die Hermeneutiek korrek. maar teen die wyse waarop hierdie taak uitgevoer word, kan ernstige besware ingebring word.

Daar word byvoorbeeld met alle mag geprobeer on die Christelike heilsboodskap onder woorde te bring in terme wat aan die moderne filosofiese begrippe-apparaat ontleen is. Die Hermeneutick moet o.m. 'n skakel lè tussen die teks en die molerne werklikheidsbegrip. soos dit ons sedert Kant begelei.

By Bultmann is dit in wese geen /lermonchliek wat ter sprake is nie, maar kenteorie. Hy definicer Hermeneutiek as die universele teorie omtrent die verstaan self. En die verstaan word dan getefinieer as "n 
lewensbetrekking. Ek kan alleen verstaan waarmee ek in lewensbetrekking staan. En nou het ons as mense een bepaalde interesse gemeenskaplik, naamlik die interesse in ons menssyn.

Wat die outeur(s) van die geskrifte uit die verlede en die leser(s) van die geskrifte in die hede met mekaar verbind is die in die menssyn gefundeerde aandag vir die grool vrae van die verwerkliking van die eie bestaan.

Omdat menssyn gelyk is aan eksisteer, is die verstaan van in teks eers dán anwesig as ek daar ..anders" van word, as die teks aan my iets doen.

() $\mathrm{m}$ oor die kloof tussen hede en verlede te kom moet ons nie let op die Bybelse voorstellingswêreld nie Daarin is hulle ook maar kinders van hulle tyd. Ons moet vra in hoever in hierdie Bybelse voorstellingswêreld 'n hele nuwe kernervaring van die mens na vore kom, naamlik die ontmoeting met God in sy Selfopenbaring: van God kan ons slegs sê wat Hy aan ons doen of watter ervaring Hy vir ons in ons menssyn beteken.

Hierdie ervaring kan egter alleen verkry word deur die .omsit" van die Bybelse ervaringswêreld in "n recks uitkristalliseringe van ervaringe van menssyn, d.w.s. deur „ontmitologisering“ toe te pas.

Tereg sê Kuitert dat die Hermeneutiek nou moet oplos waarvoor die Dogmatiek hom vroeër op die Heilige Skrif beroep het. In plaas van die (jees het die teks die laaste subjek geword. Die beroep op die (jees word as supranaturalisme beskou. M.a.w. die begrip ..openbaring" moet verstaan en gereguleer word vanuit die menssyn. Hermeneutiek is Daseinsanalyse. antropologie. uitleg van die ware menssyn. Sonder die (jees het die Hermeneutiek egter slegs die taak om die .agterhaalde Bybel" in ooreenstemming te bring met die ontwerp van die moderne mens. Funksioneel gesien vervul die Hermeneutiek hier die rol van die Apologetick. d.w.s. dit moet die Christelike geloof .akseptabel" maak!

Maar - die heilsboodskap is juis vir die sondaar onakseptahel (I Kor. 2: 14). Dic ware profect sal nooit sy boolskap verander omlat dit vir die mens onaanvaarbaar is nie ... wel die valse profeet.

Ilie .. wereldbeeld":

Hierdie vraagstuk is ook hermeneuties van aard en bring ons moontlik by die kern van die hele saak. Merkwaardigerwys word hieroor egter weinig geskrywe.

Die kontensie van die ..sekularisme-teoloe" is dat die Bybel geskryf is volgens dic wêreldbeeld van die tyd van die skrywers, ingeslote die mitologic. Sedert die twd van Copernicus het ons egter in radikaal ander wereldbeeld. wat beteken dat ons die Bybel moet oorskrywe in die terme van ons tyd en dit moet ..ontmitologiseer". Die gevolg is "n teologie wat heeltemal empiries is, heeltemal ,diesseitig". met " $n$ besliste afwysing van alles wat ..metafisies" is. Bultmann verklaar dat die boolskap van dic Skrif nie aan 'n ou. verouderde wêreldaanskouing gebonde is nie (waarin 'n element van waarheid opgeslote is. soos ons later hoop aan te toon). 
Hierteenoor staan 'n ander tilerste. soos dit o.m. aangetref word by Van Niftrik en J. A. Heyns. ${ }^{2-5}$ Hulle kontensie is dat die wêreldbeeld van dic Bybel .,ten enemale onvervangbaar" is. ondat dit oop is vir die tussenhoms van transsendentale magte. En dan volg "n vir ons onbegryplike sin: in die moderne, empiriese wêreldbeeld is dit onmoontlik om op 'n sinvole manier oor (jol en die duiwel te spreek. omdat hierdie wêreldbeeld ..geslote" is. Van Niftrik verklaar selfs dat die wêreldbeeld van die Bybel normatiewe betehenis het.

Die leser moet goed volg wat die implikasies van hierdie gedagte is: die boodskap van die Skrif is gebonde aan "n pre-Copernicanise wêreldbeeld. Daarom moet ons in ons Skrifstudie weer pre-Corpernicaans dink. As ons dit nie doen nie kan ons nie oor Giod of die duiwel spreek nie! Bultmann sê: die Bybclse boodskap is nie gebonde aan 'n verouderde wêreldbeeld nie: Van Niftrik en Heyns poncer: dic Bybelse boodskap is wel gebonde aan 'n verouderde wêreldbeeld.

$\mathrm{Na}$ ons oortuiging lî̀ die waarheid presies tussen hierdie twee uiterstes. Dit het die Here behaag om sy openbaring op "n ..organiese" wyse aan die wêreld oor te lewer, wat o.m. inhou dat liy gebruik maak van die terme ens. van die tyd. Nou het ons egter "n totaal ander wêreldbeeld en die verwagting is dat dit nog steeds gaan verander. Maur dit maak vir die werklike boodskap (die kerugma) geen verskil nie. Ons wil dus teenoor die twee uiterste rigtinge verklaar: die Woord van God is aun geen wêreldheeld (oud of muit) gehonde nie.

Kuitert verklaar tereg dat dit 'n hermeneutiese ontsporing is wanneer getuienis en klankbodem albei as absoluut verstaan word. veral as dit gepaard gaan met lundamentalisme. Hierdie prosedure het noodlottige gevolge vir dic (hristelike geloof en het as resultaat dat ander sowel die getuienis as die klankbolem relatief beskou. Die korrekte dognatiese formule moet nie 'n bedrukkende uitwerking hê nie. maar moet vry maak (Joh. $8: 32$ ).

Met nadruk moet ons ook verklaar dat die weg van Bulımann net so verwerplik is. Inmers, die wêreldbeeld sal waarskynlik as gevolg van allerlei nuwere ontdekkinge in die volgende jare radikaal verander. Volgens die standpunt van Bultmann es. sil dic Bybel dus telkens oorgeskrywe noet word.

Runia"r sề met reg dat boodskap en vorm nie geidentifiseer mag word nie. Ons mag ook nie op 'n meganiese wyse tussen dic twee onderskei nie. Die hele Skrif is as gevolg van die werk van die Heilige Gees diensbaar aan die groot soteriologiese doel en alles het sy relevansie slegs in verband met die middelpunt van die openharing. As God dus uitdrukkinge gebruik wat in daardie tye gangbaar was. sanksioneer Hy nie hierdie begrippe wat betref hulle wetenskaplike karakter nie en sy boodskap word nie daaraan geakkommodeer nie. As in die tweede gebod gespreek word van wat in dic liemel. op die aarde en onder die aarde is, word daarmee bedoel: geen skepsel hoegenaamd nie.

Die betroubaarheid van die Skrif kom hoegenaamd nie in gedrang nie. Alles wys heen na 'n ondeurgrondelike misterie waardeur (ioxl die in homseif so onvolkome menslike instrument so in sy diens neem dat 
Hy aan ons die betroubare Woord skenk wat 'n lamp is vir ons voet en ' $n$ lig vir ons pacl.":

Ons wil hier nog net die vraag stel: gee die moderne beeld van die sterrewêrelde (soos deur die reusagtige teleskope ontbloot) ons minder opening om die majesteit van die skepping van God te bewonder as die hemele wat ons met die blote oog beskou?

Soms word beweer dat hierdic standpunt 'n dualistiese gedagte aangaande die inspirasie huldig. waarvolgens wel die inhoud geïnspireer is, maar nie die vorm nie. Hierdie bewering is reeds weerlê in die woorde van Runid wat hierbo gesiteer is.

Verder word teen hierdie standpunt ingebring dat dit in die grond ook maar ontmitologisering is. Maar ook dit is besyde die waarheid. In die eerste plek: dit gaan hier nie on , mitologie" nie. Ons stem saam met G. E. Wright e.a. dat die Bybel reeds ontmitologiseer is. d.w.s. dat daarin geen mitologie voorkon wat deur ons verwyder moet word nie. Mitologie kan wesenlik slegs voorkom by die veelgodedom met hulle onderlinge twiste. Dan -. dit gaan hier nie oor agtergrondsake nie. maar oor die (voorwetenskaplike) voorstelling van die heelal. inklusief die mens, en die vraag of hierdie benadering vir ons nog normiatief is. Moet ons byvoorbeeld nog aanneem dat daar 'n doderyk (Sjeool) onder die aarde is"? Moet ons aanncem dat die brein van die mens hoegenaamd geen funksic het nie, ondat dit in die Bybel nie vermeld word nie? Tereg het $H$. Bavinck al opgemerk dat die ont dekkinge van Copernicus e.a. ons daarop gewys het dat ons die ...stilstaan van die son" in die tyd van Josua anders moet verklaar. Dit help eenvoudig nie meer om oogklappe aan te sit nie. selfs ons kinders sien hierdie dinge raak.

As Bultmann e.a. beweer dat ons in die moderne wêreldbeeld geen plek meer het vir 'n hemel en geeste (engele en duiwels) nie, dan toon dit maar net hulle volslae empirisme. Die skrywer hiervan het hom in die jongste tyd intensief besig gehou met die natuurwetenskappe in verband met die evolusionisme en tot die konklusie gekon dat by die natuurwetenskaplikes 'n teenoorgestelde neiging as dié van die eksistensieteoloë waargencen word. IVaar laasgenoemde net wil bly by wat hulle verstand kan verstaan is daar verskillende groot natuurwetenskaplikes wat crken dat daar misteries is wat hulle verbyster. (Ons dink veral aan die ontdekkinge van Planck. Heisenberg. Einstein en andere.

As ons die hemel met teleskope wil soek sal dit seker op teleurstelling uitloop. Die grense van die geskape heelal is nog nooit bereik rie. Dit gaan hier on sake van die geleof. Die hemel verteenwoordig in heeltenal ander orde van dinge.

In verband met die hele vraagstuk moet ook daaraan gedink word dat vanouds onclerskei is tussen historiese en normutielie gesag van die Skrif. asook dat daar n geskiedenis van die openbaring is. Die seremonies van die wet is byvoorheeld nie meer vir die Christen normatief nie (vgl. die brief aan die (jalasiërs). 
Thielicke het met reg verklaar: "Nicht unser Weltbild, sondern dic damit vereinigte. aber keineswegs 'gegebene' Weltanschauung von der in sich ruhende Endlichkeit, bildet dan entscheidenden Hinderungsgrund unseres Glaubens"."

\section{Wat moet gestel word teenoor die .anti-metafisiese" teologie?}

Ons wil saamstem met Kuitert as hy daarteen waarsku dat ons uit onbehae teenoor hierdie teologie gaan teruggryp op die sg. ..metafisiese teologie" van die sewentiende en agttiende eeue. met verloëning van die lig wat in die arbeid van Luther en Calvyn opgegaan het. of in die hande val van in eksistensieteologie wat eweseer die Reformasie verloën.

Ons moet dus vashou aan ons oorgelewerde geloofigoed. Skrif en Belydenis, sonder verwaarlosing van blywend-waardevolle elemente by latere teoloë wat voortgebou het op die reformatoriese erfenis, soos Kuyper en Bavinck. Wat ook weer nie beteken dat die kerk en die teologie van hulself museumstukke moet maak nie. Jeur die oë te sluit vir dit wat nuwere ontdekkinge kan bring, ook met betrekking tot die verklaring van die Skrif. Dit is opmerklik dat die kerk eers as gevolg van die ontdekkinge van Galilei en sy navolgers werklik afskeid kon neem van die Aristoteliese metafisika.

Tereg sê I.oen" dat ons by die vraagstukke rondom die sekularisme eksistensieel betrokke is. En die hoofvraag is: die "Frage (ioltes". "Säkularisation (sekularisme!) ist der historische Prozess in dem die Welt entgöttlicht wird", nie in die sin dat Gol eers werklik aanwesig was en later nie meer nie. maar in die sin dat die wêreld vir die menslike hewussyn ..entgöttlicht" is. In die raam van die Bybelse denke kan sekularisasie net beteken: verwêreldliking, aan hierdie wêreld gelyk. vormig word (vgl. Rom. $12: 2$ in die Vulgaat: nolite conformari huic saeculo). Die saeculum van die Vulgata is in vertaling van die (iriekse aioon en hierdie woord beteken die "gekwalifiseerde era". Fintlik is die vertaling van die twee woorde deur .,wêreld" nie ideaal nie. omdat hierdie woord in die N.T. oorwegend met kosmoss-mundus weergegee word. in die briewe van Johannes selfs uitsluitlik.":

Volgens l.oen sê Rom. 12:2 wat die Bybel onder sekularisme verstaan: $m^{\bar{i}}$ syschematizesthe töi aiöni toutöi - nolite conformari huic saeculo - word nie gelykvormig aan hierdie era nie. En dan: ..word omgevorm deur die vernuwing van julle denke". soos dit letterlik staan. Dit beteken dat hulle hul in die sedelike beslissinge deur die openbaring van God noet laat lei, nie deur die eie verdorwe verstand nie - die teenoorgestelde dus van sekularisme. (Om die ware schema van hierdie aikon uit te lewe beteken om op weg te wees vanaf pinkster na die wederkoms van Christus.

As Paulus dus praat van nie-gelykvormig word aan dic schema van hierdie aioon nie, bedoel hy met schema nie die ware wese dar. van nie. maar die skingestalte wat ontstaan as die bepalaldheid van hierdic tyd deur sy posisie in die heilsgebeure vergeet word. Dan wil die tyd en die mensewereld selfstandig wees en sy eie gestalte vorm. 
Wat is dié gestalte'? In lukas 16:8 word onderskei tussen die kinders van hierdic aiom en die kinders van die lig. Die skema van hierdie aioon is dus sonder meer die duisternis in teenstelling tot die lig. Maar die duisternis is nie iets positiefs nie - slegs die afwesigheid van lig. Daarom kan die kinders van hierdie era geen selfstandige eksistensie opbou nie. Hulle behoort net tot 'n skyngestalte. Daarom word hulle wel phromimoi genoem maar nic sophoi nie. By hulle staan die vergeefsheid. die verydeling op die voorgrond. Die tyd van hierdie aioon is die tyd van die negativa: sorge, bedrog van die ryk(lom. begeerte na alle ander dinge (Markus 4:19: hui merimmai tou aionos).:3i

In Ef. $2: 2$ word hierdie aimon in parallellie geplaas by die owerste van die maghebbers van die duisternis en die gees wat nou werk in die kinders van die ongeregtigheid. Die verontagsaming van die heilsgebeure is apeihheia (ongehoorsaamheid) en in wese demonies. Tot sover die eksegese van L.oen.

Wat 'n ironie dic mense wat beweer dal daar geen God. geen engele en geen duiwels is nie. is juis betrokke in in demoniese apeitheia!

Wat moet hierleenoor gestel word? Kernagtig sê Van Niftrik ${ }^{3 *}$ dat ons in die eerste plek weer sal moet leer on die gewone man te bereik. (Ons moet die mense lei na Jesus Christus. wat by iollenaars sit. Jesus wat sonder kramp en vry. soos die lelies van die veld, onder die hemel lewe en die mense oproep om die lewe te vind in die gee. in die wéggee.

As voorbeekle van teoloë wal ook die gewone man bereik het. noem Van Niftrik spesiaal Calvyn en Kuyper. Die huidige dogmatiese werke is slegs vir die ingewyde en die Dogmatiek loop altyd gevaar on 'n gnosis te word. Die ware Dogmatick sal moet aantoon dat dit in die Skrif primer gaan om (jod en nie om die handhawing van die menslike eksistensie nie. Teenoor Van Buren e.a. sal die teologie moet opkom vir die uilgieting van die nardus van die aanbidding. vir die gehoorsaamheid aan die eerste en die groot geboul.

Kuitert meen dat die Roomse in Nederland in hierdie opsig in voorbeell gestel het met die nuwe kategismus. Hulle het aan die gemeentelede leiding gegec - - in pastorale daad van belang. Deur Gereformeerdes word nog te reel gedink dat ..pastoraal" beteken: so weinig moontlik nuwe dinge bring en as dit dan noet in die kleinste moontlike verdunning. Die gemeente mag nie verontrus en in verwarring gebring word nic. Dic sorg vir die kudde kan egter ook daarin bestaan dat ons liewer in halwe slag voor as 'n halwe slag agter is. Die gemeente moet nie soos onvolwasse kinders behartig word nie.

Reformatoriese (hristene behoort dit baie makliker te kan doen as dic Romse. omdat hulle nie grootgebring is onder die gedagte van "Il onfeilbare herklike leergesag nic."

Met die anpak van Kuitert in sy te realiteit ran het gelenf kan ons onssclf grosso modo verenig. maiar dit wil ons tog voorkon of hy. hoewel hy attent maak op die spekulatiewe element by feitlik al dic 
eksistensieteoloë, self tog ook veelal te spekulatief redeneer. Kuitert spreek dikwels oor die Hermeneuse. maar hy sien dit meer as 'n hulpvak by die Dogmatiek, Jan as basis van die Eksegese. Die beginsels vir die Hermeneutiek moet aan die Skrif self ontleen word.

Spekulasie is veelal die fout van Duitse teoloè. ook van dié wat na Amerika verhuis het! G. P. Hartvelt slaak die volgende versugting: "Het zou van enig belang zijn wanneer wij in Nederland niet de situatie krijgen van "het mandarijnendom der Duitse universiteitsteologie' (Berkhof)," waar dit teologiseer oor die hoofde van die mense heen op koste van die belastingbetaler!

Indien die Gereformecrde teologie werklik 'n geluid van betekenis wil laat hoor in 'n tyd van sekularisme. sal dit gedurig op sy hoede moet wees vir skolastiese elemente in sy erfenis en op voetspoor van die Reformatore soek na die ..Schriftbeginselen ter Schriftverklaring" (Greydanus), on dan na grondige eksegese die ewige e'ungelie te bring aan 'n wêreld wat siek en vermoeid is.

Ons kan óók eksistensieel spreek. (Ons kan oók eerlik teenon" (Goll wees. Ons glo dat die evangelie nie net die hoof raak nie. maar ons hele eksistensie. Ons hoef nie oogklappe aan te sit in ons verkondiging nie, maar ons kan die moderne mens met al sy probleme reëlreg in die oe kyk. Daar is niks om weg te steck nie. niks te verdoesel nie. Natuurlik bly daar nog baie oor wat ons soms moeite gee. Maar die skrywer hicrvan kan getuig dat die Skrif in sy egle. en daarom blywende, kerugina vir hom altyd wonderliker word en dat steeds nuwe dieptes oopgaan.

INota: Nadat die kopie van hierdie artikel reeds ingehandig was. het die tweede deel van Berkouwer se De Heilige Schrift ons ter hand gekom. Omdat hy ten opsigte van die ..wereldbeeld" van die Bybel prakties dieselfde standpunt inneem, word enkele van sy gedagtes hier weergegee:

Alle besinning oor die .,aansluiting" by die eie tyd van die Bybel val altyd weer in die skadu van die dualisme. So maklik kan die akkommodasiegedagte insluip, naamlik die reduksie van die Skrif tot 'n kern. Die vraag wat altyd weer terugkeer is: Hoe is dit moontlik om te onderskei tussen die inhoud en die vorm. die boodskap en sy ekspressie? Die gekompliseerdheid en die gevare van 'n onderskeiding het gelei tot afwysing van elke onderskeiding. HIke dualisme en elke verifikasiemetode moet oorwin word. ...Meer en meer dringt echter het besef door, dat deze apriorische afwijzing van elke muancering en van de concrete bezinning over de atard van het Schriftgezag niet valt te handhaven .....". Teenswoordig word in hierdie verband op die skopus van die Skrif gewys en die vrees dat hierdie skopus-idlee tot willekeurige dualisme en aantasting van die gesag van die Skrif sal lei. berus nie alleen op 'n misverstand nie, maur misken ork die erms e'n die diepte ran die Bybelse boodskup.

Berkouwer wys daarop dat prof. I. Ridlerbos reeds jare gelede die volgende geskryf het: "Voorts vertomnt de Schrift de kenmerken van de tijd en van het milieu, waarin ze is ontstaan en deze kennerken 
zijn ten dele weer gemeen aan heel het oosterse geestesleven. waarmee dat van Israël op allerlei wijze samenhangt. Dit geldt ten opzichte van schrift, taal. stijl. litteraire genres. voorstellingen, begrippen. wereldbeeld (vgl. de driedeling van het heelal in Ex. 20:4)".

Die erns warmee sekere skrywers teen hierdie gedagtes opereer sal op die dunr meer skade doen an die eerbied vir die Skrif as dat dit daurop sul verheter. . . . Deur die verstaan van die tydbetrokkenheid van die Heilige Skrif kan 'n mens 'n oog kry vir die ware en blywende normatiwiteit van die Woord van God .... Dit gaan om die tydhetrokkenheid van die Skrif en om die universele gesag daarvan (bl. 68 v. - kursivering van ons) ।

(Gelewer voor G.T.V.

Prof. S. du Toit.

Witwatersrand en Potchefstroom. 1967)

\section{VERWYSINGE}

1. In Chr Encyclopacdie: s.t. secularisatie.

2. Leslie Neubigin, Honest Religion for secular man, SCM-Press. London. 1966. $p .8 \mathrm{v}$.

3. In 'n artikel in die Almumah van die Geref. Kerke (art. 311). 1966.

4. Vgl. F. H. Klooster in Calvin Theol. Journal, Apr. 1967, p. 27.

5. Aangehaal ibid. p. 28.

6. So lui die subtitel ian sy werk the realiecit van het geloof, Kampen. Kok. 1966.

7. Kuitert. a.u., p. 14 v.

8. Kuitert. a.t. p. 23.

9. A.1.. p. 24, 25.

10. Kuitert. a.W.. p. 26 \%.

11. A a., p. 92.

12. A.a.. p. 95 v.

13. Kerk en Theologie. Jan. 1965. p. 15.

14. Vgl. Bremmer. a.a., p. $1(14$.

15. In Cals. Theol. Journal, Apr. 1967. p. 32. 33.

16. Aangehaal deur Klooster. a.a.

17. A.a., p. 101-103.

18. Hier volg ons die genoemde werke van Kuilert. Porteous en Heyns.

19. Vgl. Heyns, a.w.. j. 7.

20. A.a. p. 18.

21. Kuitert, a.w., p. 91.

22. A.a., p. 107.

23. A.a. p. 108 .

24. Vgl Wending, Junic 1965. p. 219. 220.

25. In aangehaalde art. en boek resp.

26. In: Kart Barth's Docirinc of Holy Scripture, Grand Rapids. 1962. p. 89 v.

27. Vgl. Berkouwer. H't prohleem der Schrificritich. Kampen. Kok. s.j.. p. 352

28. Aangehaal deur Van Niftrik. a.a.

29. In sy mooi werk Sähularisation, München. Kaiser Verlag. 1965. p. $164 \mathrm{v}$. Hy gebruik hlykhaar die woord ..sekularıasie" in die sin van ..sckularisme".

30. A.W.. p. 61.

31. L.ein. a.w.. p. $166 \mathrm{v}$.

32. A.a. p. 33.

33. Vgl. Hending, Feb) 1967, p 852 